\title{
Biochemical Improvement after Treatment by Bone Marrow Transplantation in I-Cell Disease
}

\author{
Inuo Kurobane, Shigeo Inoue, Yoh-Ichi Gotoh, \\ Seitchi Kato, Makoto Tamura, ${ }^{*}$ Kuniaki Narisawa and \\ KeIYA TADA \\ Department of Pediatrics and *Blood Transfusion Service, \\ Tohoku University School of Medicine, Sendai 980
}

\begin{abstract}
Kurobane, I., Inoue, S., Gotoh, Y-I., Kato, S., Tamura, M., Narisawa, K. and TADA, K. Biochemical Improvement after Treatment by Bone Marrow Transplantation in I-Cell Disease. Tohoku J. exp. Med., 1986, 150 (1), 63-68 The first case of successful bone marrow transplantation (BMT) in a patient with I-cell disease is reported. A 8-month-old girl with I-cell disease (Nacetylglucosaminylphosphotransferase deficiency) has had successful reconstitution with bone marrow from her HLA-MLC-matched brother who has heterozygous level of the transferase activity. The following biochemical and clinical improvements have occurred: the transferase in peripheral lymphocytes increased to donor's level, and lymphocytic $\alpha$-neuraminidase, $\beta$-galactosidase and $\alpha$ mannosidase increased to normal levels. Plasma acid hydrolase activities, which had been 10 to 60 times higher in the patient than normal control levels, have slowly but steadily decreased from one month after the graft. Such decreases were observed in the activities of $\alpha$-mannosidase, $\mathrm{N}$-acetyl- $\beta$-glucosaminidase, $\alpha$ fucosidase, arylsulfatase A and acidic $\beta$-galactosidase. There was also a marked decrease of vacuolated peripheral lymphocyte after the BMT. Three-months after the engraftment, hepatomegaly gradually decreased in size, corneal clouding has not progressed, and tight skin seems to have improved.—bone marrow transplantation; I-cell disease; $\mathrm{N}$-acetylglucosaminylphosphotransferase ; plasma acid hydrolases
\end{abstract}

With a significant progress in technique and managemant for bone-marrow transplantation (BMT), BMT has been proposed for the treatment of inherited lysosomal storage diseases. More recently, several lysosomal enzyme deficiencies have been successfully treated with BMT in view of biochemical and clinical effects (Hobbs 1981; Barranger 1984).

I-cell disease has an autosomal recessive mode of inheritance and is caused by a deficiency in the activity of the enzyme N-acetylglucosaminylphosphotransferase (GlcNAcPTase), which is required for the transport of acid hydrolases into lysosomes (Neufeld and McKusick 1983). A number of acid hydrolases are partially and profoundly deficient in cultured skin fibroblasts of

Received June 4, 1986; accepted for publication July 10, 1986. 
patients but the enzymes altered are strikingly elevated in plasma and other body fluids. Many inclusions of mesenchymal cells result in the clinical features of the disorder. Death usually occurs before the age of 5 years.

In this report, we describe the biochemical findings 3 months after successful BMT in a 8-month-old girl with I-cell disease.

\section{Case-Report}

A 4-months-old girl with I-cell disease was admitted to the Tohoku University Hospital. She had Hurler-like coarse face, gingival hyperplasia, corneal clouding, tight skin, hepatomegaly and chest deformity. x-ray examinations confirmed dysostosis multiplex in the vertebral bodies, pelvis, extremities and chest, and revealed the subluxation of hip joint. In addition, peripheral lymphocytic vacuolization was noticed. Several acid hydrolases of her plasma and urine were 10 to 60 times higher than normal levels, and there were numerous phase-dense inclusion bodies in her cultured fibroblasts. The diagnosis was established by the demonstration of deficient activity in lymphocyte GlcNAcPTase.

Since 3 months of age she had recurrent obstructive apneic episodes. At 8 months of age progressive cardiac dysfunction, increasing hepatomegaly and joint limitation were noted. The risk of the BMT was fully explained to her parents, and informed consent was obtained from her parents for the transplantation.

BMT was done with conventional techniques (Hobbs 1981). The preparative regimen for BMT consisted of busulfan $(4 \mathrm{mg} / \mathrm{kg})$ on Day $-9,-8,-7,-6$, and -2 , and cyclophosphamide $(50 \mathrm{mg} / \mathrm{kg})$ on Day $-5,-4,-3$, and -2 . The donor was the patient's HLA identical and mixed lymphocyte culture negative brother, who was heterozygous for GlcNAcPTase deficiency. The graft-versus-host preventive regimen consisted of cyclosporin A daily dose of $12.5 \mathrm{mg} / \mathrm{kg}$ (Gluckman et al. 1984 ; Hugh-Jones et al. 1984). Her general course was unremarkable. No evidence of graft-versus-host disease was observed.

On day 60 post graft, $60 \%$ of peripheral blood lymphocytes cultured with phytohemagglutinin were male, indicating a definite chromosomal evidence of engraftment. Seven months after engraftment, hepatomegaly was substantially decreased, corneal clouding has not progressed, and tight skin has improved. Furthermore, the immunologic disturbances including defective cellular immunity are also improving. However, no improvement of skeletal changes has been observed yet.

\section{Methods}

Lymphocytes were isolated from $10 \mathrm{ml}$ of heparinized blood using FicollPaque technique, and homogenized in distilled water. Lymphocytic $\alpha$ mannosidase $(\alpha$-Man) and $\beta$-galactosidase $(\beta$-Gal) levels were measured by the method of VanHoof and Hers (1968), and its $\alpha$-neuraminidase ( $\alpha$-Neu) activity by the method of O'Brien (1982). A sensitive and reliable assay was performed for the GlcNAcPTase in lymphocyte, which uses $\alpha$-methylmannoside as an acceptor, developed by Varki and Reitman (1982) with slight modifications. Plasma and urine acid hydrolases were assayed by the methods of DenTandt, Glaser and Sly with a modification using 4-methylumbelliferyl or $p$-nitrocatechol derivatives as substrates of the enzymes (Glaser and Sly 1973; DenTandt and Philippart 1974). 


\section{Results}

The activity of lymphocyte GlcNAcPTase was found to be increasing by day 48 , has reached the I-cell heterozygote level by day 60 , and thereafter has remained in this level for the following 3 months (Table 1). Lymphocytic activities of some lysosomal enzymes such as $\alpha$-Neu, $\alpha$-Man, and $\beta$-Gal also became normal levels, or even above normal sometimes. Peripheral vacuolated

TABLE 1. Serial lymphocytic activity of GlcNAcPTase and lysosomal enzymes

\begin{tabular}{lcccc}
\hline & $\begin{array}{c}\text { GlcNacPTase } \\
(\mathrm{pmole} / \mathrm{mg} / \mathrm{hr})\end{array}$ & $\alpha$-Neu & $\beta$-Gal & $\alpha$-Man \\
\cline { 4 - 5 } & & & $(\mathrm{nmole} / \mathrm{mg} / \mathrm{hr})$ & \\
\hline Patient & 0 & 1.62 & 59.7 & 12.7 \\
$\quad$ Before BMT & & & & \\
$\quad$ After BMT (days) & 41.5 & 2.09 & 74.9 & 132.1 \\
$\quad 48$ & 156.5 & 6.28 & 183.7 & 71.9 \\
$\quad 60$ & 143.7 & 3.39 & 181.9 & 74.8 \\
$\quad 88$ & 148.3 & 3.02 & 148.3 & 75.0 \\
Brother (donor) & $227.0 \pm 23.6$ & $3.90 \pm 1.20$ & $171.3 \pm 49.2$ & $56.8 \pm 14.8$ \\
Normal values $(n=10)$ &
\end{tabular}

$\alpha$-Neu, $\alpha$-neuraminidase ; $\beta$-Gal, $\beta$-galactosidase ; $\alpha$-Man, $\alpha$-mannosidase. Normal values are expressed as mean \pm s.D.

TABLE 2. Serial activities of plasma acid hydrolases

\begin{tabular}{cccc}
\hline & $\alpha$-Man & $\beta$-Hex & ASA \\
\cline { 2 - 4 } & \multicolumn{3}{c}{$(\mathrm{nmole} / \mathrm{ml} / \mathrm{hr})$} \\
\hline Patient & 2,056 & 8,838 & 2,524 \\
Before BMT & 2,056 & 9,588 & 2,730 \\
& & & \\
After BMT (days) & 1,899 & 8,099 & 2,657 \\
13 & 1,468 & 6,952 & 2,448 \\
19 & 1,048 & 6,021 & 1,738 \\
48 & 1,170 & 5,941 & 1,504 \\
58 & 1,213 & 5,646 & 1,351 \\
89 & 960 & 5,919 & 1,323 \\
111 & 1,198 & 6,702 & 1,286 \\
134 & 936 & 5,782 & 1,073 \\
160 & 1,216 & 7,418 & 1,266 \\
190 & $157.7 \pm 53.0$ & $607.5 \pm 171.4$ & $62.7 \pm 21.9$ \\
\hline
\end{tabular}

$\beta$-Hex, $\mathrm{N}$-acetyl- $\beta$-glucosaminidase; ASA, arylsulfatase. A Normal values are expressed as means \pm S.D. 
lymphocytes have been present $20 \%$ to $30 \%$ in the recipient's lymphocytes before BMT. Their numbers have dramatically reduced to $1 \%$ to $5 \%$ of peripheral blood lymphocytes after graft for 100 days. In addition, many plasma acid hydrolase activities such as $\alpha$-Man, $\mathrm{N}$-acetyl- $\beta$-glucosaminidase $(\beta$-Hex) or arylsulfatese A (ASA) have decreased after graft until 2 or 3 months later, and after that have fluctuation around a plateau (Table 2). Especially plasma $\alpha$-Man activity showed a progressive decrease from elevated level before BMT to half value by 89 days. Such finding was also observed in other acid hydrolases such as $\alpha$-fucosidase and $\beta$-Gal ( $\mathrm{pH} 3.5$ ) (data not shown).

\section{Discussion}

BMT may be beneficial in the treatment of lysosomal storage diseases because bone-marrow-derived cells are a source of lysosomal enzymes and because the origin of tissue macrophages such as those of liver (Gale et al. 1978), lung (Thomas et al. 1976), and even in brain is in the bone marrow (Fujita and Kitamura 1976 ; Bayever et al. 1985). More recently, several lysosomal enzyme deficiencies, including mucopolysaccharidoses (Hobbs et al. 1981; Hugh-Jones et al. 1984 ; Krivit et al. 1984), Gaucher's disease (Rappeport and Ginns 1984), metachromatic leukodystrophy (Bayever et al. 1985), and adrenoleukodystrophy (Moser et al. 1984), have been successfully treated by BMT in view of biochemical and clinical effects.

This is the first case of BMT for I-cell disease which has metabolic property different from the other disorders of single lysosomal enzyme deficiency. The elevation of the activities in lymphocytic lysosomal enzymes and GlcNAcPTase after BMT is regarded as biochemical evidence of the engraftment. Despite the chimeric engraftment of peripheral lymphocyte, the patient's lysosomal enzyme activities have reached the donor's enzyme level or above. This result suggests the possibility that some circulating humoral factor is responsible for a compensatory increase in the activity of lysosomal enzymes in the donor's cells. The most striking aspect of the present results is that several acid hydrolases activities in plasma have slowly but steadily decreased after transplantation. However, the mechanism for the decrease of the plasma enzyme activities remains unclear.

The decreased hepatic mass, improvement of tight skin, nonprogressive corneal clouding and spontaneous recovery of hip joint subluxation provide clinical evidence that the BMT has altered the progress of her disease. However, it is too early to decide if BMT is an effective treatment for I-cell disease. Long-term evaluation will be required to document subsequent clinical improvement including developmental acquisition.

\section{Acknowledgments}

We are indebted to her brave family, whose courage and cooperation made this work possible; to the staff of Department of Pediatrics, Bacteriology Section, Central Laboratory 
Tohoku University Hospital for continued support ; to the nursing staff for their expert care and devotion to the patient, Dr. Hiroshi Nakagawa and Dr. Takeo Sakai, Sendai City Hospital, referred the patient.

\section{References}

1) Barranger, J.A. (1984) Marrow transplantation in genetic disease. New Engl. J. Med., 331, 1629-1630.

2) Bayever, E., Ladisch, S., Philippart, M., Brill, N., Nuwer, M., Sparkes, R.S. \& Feig, S.A. (1985) Bone-marrow transplantation for metachromatic leukodystrophy. Lancet, 2, 471-473.

3) DenTandt, W.R. \& Philippart, M. (1974) Leory's I-cell disease : markedly increasd activity of plasma acid hydrolases. J. Lab. clin. Med., 83, 403-408.

4) Fujita, S. \& Kitamura, T. (1976) Origin of brain macrophages and the nature of microglia. Prog. Neuropath., 3, 1-50.

5) Gale, R.P., Sparkes, R.S. \& Golde, D.W. (1978) Bone marrow origin of hepatic macrophages (Kupffer cells) in humans. Science, 201, 937-938.

6) Glaser, J.H. \& Sly, W.S. (1973) $\beta$-Glucuronidase deficiency mucopolysaccharidosis : Methods for enzymatic diagnosis. J. Lab. clin. Med., 82, 969-977.

7) Gluckman, E., Devergie, A., Poirier, O. \& Lokiec, F. (1984) Use of cyclosporine as prophylaxis of graft-versus-host disease after human allogenic bone marrow transplantation: Report of 38 patients. In : Cyclosporine: Biological Activity and Clinical Applications, edited by B.D. Kahan, Grune-Stratton, Inc., Orland, pp. 412-418.

8) Hobbs, J.R., Hugh-Jones, K., Barrett, A.J., Byrom, N., Chambers, D., Henry, K., James, D.C.O., Lucas, C.F. \& Rogers, T.R. (1981) Reversal of clinical features of Hurler's disease and biochemical improvement after treatment by bone-marrow transplantation. Lancet, 2, 709-712.

9) Hobbs, J.R. (1981) Bone marrow transplantation for inborn errors. Lancet, 2, 735739 .

10) Hugh-Jones, K., Hobbs, J.R. \& Chambers, D. (1984) Bone marrow transplantation in mucopolysaccharidoses. In: Molecular Basis of Lysosomal Storage Disorders, edited by J.A. Barranger \& R.O. Brady, Academic Press, Inc., Orlando, pp. 411-428.

11) Krivit, W., Pierpont, M.E., Ayaz, K., Tsai, M., Ramsay, N.K.C., Kersey, J.H., Weisdorf, S., Sibley, R., Snover, D., McGovern, M.M., Schwartz, M.F. \& Desnick, R.J. (1984) Bone-marrow transplantation in the Maroteaux-Lamy syndrome (Mucopolysaccharidosis type VI). New Engl. J. Med., 311, 1606-1611.

12) Moser, H.W., Tutschka, P.J., Brown, F.R., Moser, A.E., Yeager, A.M., Singh, I., Mark, S.A., Kumar, A.A.J., McDonnell, J.M., White, C.L., Maumenee, I.H., Green, W.R., Powers, J.M. \& Santos, G.W. (1984) Bone marrow transplantation in adrenoleukodystrophy. Neurology, 34, 1410-1417.

13) Neufeld, E.F. \& McKusick, V.A. (1983) Disorders of lysosomal enzyme synthesis and localization: I-cell diseease and pseudo-Hurler polydystrophy. In: The Metabolic Basis of Inherited Disease. 5th ed., edited by J.B. Stanbury, J.B. Wyngaarden \& D.S. Fredrickson, McGraw-Hill, Inc., New York, pp. 778-787.

14) O' Brien, J.S. (1982) Sialidosis. In: Genetic Errors of Glycoprotein Metabolism, edited by P. Durand \& J.S. O' Brien, Springer-Verlag, Inc., Milano, pp. 45-46.

15) Rappeport, J.M. \& Ginns, E.I. (1984) Bone marrow transplantation in severe Gaucher's disease. New Engl. J. Med., 311, 84-88.

16) Thomas, E.D., Ramberg, R.E., Sale, G.E., Sparkes, R.S. \& Golde, D.W. (1976) Direct evidence for a bone marrow origin of the alveolar macrophage in man. Science, 192, 1016-1018.

17) VanHoof, F. \& Hers, J.G. (1968) The abnormalities of lysosomal enzymes in mucopolysaccharidoses. Europ. J. Biochem., 7, 34-44. 
18) Varki, A. \& Reitman, M.L. (1982) Demonstration of the heterozygous state for I-cell disease and pseudo-Hurler polydystrophy by assay of $\mathrm{N}$-acetylglucosaminylphosphotransferase in white blood cells and fibroblats. Amer. J.hum. Genet., 34, $717-729$. 